\title{
Human ovarian tissue vitrification versus conventional freezing: morphological, endocrinological, and molecular biological evaluation
}

\author{
V Isachenko, I Lapidus ${ }^{1}$, E Isachenko, A Krivokharchenko ${ }^{1}$, R Kreienberg, M Woriedh, \\ $M$ Bader $^{1}$ and J M Weiss \\ Department of Obstetrics and Gynaecology, University of Ulm, Prittwitzstrasse 43, 89075 Ulm, Germany and \\ ${ }^{1}$ Max-Delbrück Center for Molecular Medicine, Robert-Rössle-Strasse 10, 13125 Berlin, Germany
}

Correspondence should be addressed to V Isachenko; Email: v.isachenko@yahoo.com

\begin{abstract}
Cryopreservation as a process can be divided into two methods: conventional freezing and vitrification. The high effectiveness of vitrification in comparison with conventional freezing for human oocytes and embryos is shown, whereas data on human ovarian tissue are limited. The aim of this study was to compare the safety and effectiveness of conventional freezing and vitrification of human ovarian tissue. Ovarian tissue fragments from 15 patients were transported to the laboratory within 22-25 $\mathrm{h}$ in a special, isolated transport box that can maintain a stable temperature of between 5 and $8{ }^{\circ} \mathrm{C}$ for $36 \mathrm{~h}$. Small pieces of ovarian tissue $(0.3-1 \times 1-1.5 \times 0.7-1 \mathrm{~mm})$ were randomly distributed into three groups: group 1, fresh pieces immediately after receiving transport box (control); group 2, pieces after vitrification; and group 3, pieces after conventional freezing. After thawing, all the pieces were cultured in vitro. The viability and proliferative capacity of the tissue by in vitro production of hormones, development of follicles, and glyceraldehyde 3-phosphate dehydrogenase $(G A P D H)$ gene expression after culture were evaluated. A difference between freezing and vitrification was not found in respect to hormonal activity and follicle quality. The supernatants showed $17-\beta$ estradiol concentrations of 365,285, and $300 \mathrm{pg} / \mathrm{ml}$ respectively, and progesterone concentrations of $3.82,1.99$, and $1.95 \mathrm{ng} / \mathrm{ml}$ respectively. It was detected that 95,80 , and $83 \%$ follicles respectively were morphologically normal. The molecular biological analysis, however, demonstrated that the GAPDH gene expression in ovarian tissue after vitrification was dramatically decreased in contrast to conventional freezing. For cryopreservation of human ovarian tissue, conventional freezing is more promising than vitrification, because of higher developmental potential.

Reproduction (2009) 138 319-327
\end{abstract}

\section{Introduction}

In 2008, 692000 women were diagnosed with cancer in the United States of America alone (Jemal et al. 2008). Because of the increasing effectiveness of oncological treatments (Grovas et al. 1997, Jemal et al. 2008), young women seek for a chance to regain their reproductive potential after treatment. This can be achieved by the cryopreservation of ovarian tissue before medical intervention. Therefore, cryopreservation of human ovarian tissue has become one of the main research projects in reproductive medicine. In 1996, the first case of cryopreservation of human ovarian tissue with good survival of follicles after warming was published (Hovatta et al. 1996, Hovatta 2005). Childbirth after cryopreservation of ovarian tissue is now a reality (Donnez et al. 2004, Meirow et al. 2005, 2007a, 2007 b, Demeestere et al. 2007, Andersen et al. 2008).

The use of cryopreserved ovarian tissue is not only limited to reproduction. There are reports of patients with premature ovarian failure after cancer treatment and restoration of ovarian function after re-implantation of cryopreserved ovarian cortex (Donnez \& Bassill 1998, Oktay et al. 1998, 2004, Oktay \& Karlikaya 2000, Callejo et al. 2001, Meirow \& Nugent 2001, 2007b, Radford et al. 2001, Gosden 2005, Schmidt et al. 2005, Silber et al. 2005, Wolner-Hanssen et al. 2005, Demeestere et al. 2006, Donnez et al. 2006a, 2006b, 2008, Rosendahl et al. 2006, Bedaiwy \& Falcone 2007, Meirow et al. 2007b, Silber \& Gosden 2007). Therefore, cryopreservation of human ovarian tissue cannot be limited only for restoration of reproductive function (pregnancy after oncological treatment), but also can be used for therapeutic purposes (Isachenko et al. 2008a).

Cryopreservation of ovarian tissue can be performed using one of two methods: conventional ('slow') freezing and cryopreservation by direct plunging into liquid nitrogen (so called vitrification or rapid 'freezing'). Comparative investigations of vitrification 
and conventional freezing performed on mammalian ovarian tissue are limited, and authors present different conclusions. For example, it has been shown that for human ovarian tissue, conventional freezing is more efficient than vitrification (Gandolfi et al. 2006). Furthermore, it was established that conventional freezing is a suitable method for cryopreservation of ovarian tissue with better follicle quality and hormonal activity (Isachenko et al. 2007). However, it also has been reported that there is no difference in the quality of the follicles and the hormonal activity between conventional and rapid freezing (Li et al. 2007).

In addition to former studies, we here tested the proliferative potential of human ovarian tissue at the molecular biological level. Glyceraldehyde 3-phosphate dehydrogenase $(G A P D H)$ is a housekeeping gene and plays a crucial role in glycolysis and in several other metabolic and non-metabolic processes (Sirover 1996, 1997). Analysis of GAPDH gene expression is a marker for variations in the amount of intact RNA after an experimental treatment of tissues (in our case this is cryopreservation; Barber et al. 2005).

The aim of this study was to compare the safety and effectiveness of vitrification and conventional freezing of human ovarian tissue by assessing follicular quality, production of hormones, and GAPDH gene expression.

\section{Results}

\section{Histological examination}

After the in vitro culture of ovarian pieces, only primordial as well as primary and secondary follicles were denoted as viable. All the antral follicles after cryopreservation and in vitro culture were degenerated, and we have not counted these follicles. The mean primordial follicle density per $1 \mathrm{~mm}^{3}$ for group 1 was $11.1 \pm 2.1$; for group 2 was $12.0 \pm 6.2$; and for group 3 was $11.9 \pm 4.6(P>0.1)$. It was detected that 95,80 , and $83 \%$ follicles for groups 1,2 , and 3 respectively were normal $\left(P_{1-2,3}<0.05, P_{2-3}>0.1\right.$; Figs $\left.1-3\right)$.

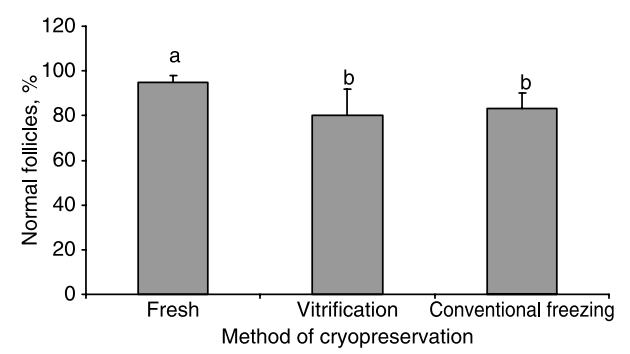

Figure 1 Quality of follicles (expressed as percentage of normal follicles) after vitrification and freezing of ovarian pieces. Different superscripts indicate statistical difference $(P<0.05)$.
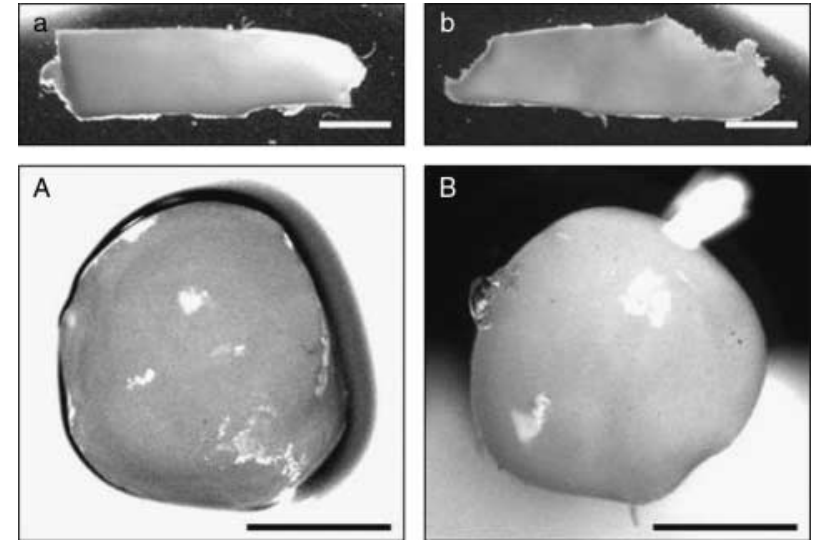

Figure 2 Light micrographs of ovarian pieces (OP) from the same patient: (a) fresh OP, (A) OP after vitrification and culture; (b) fresh OP, (B) OP after conventional freezing and culture by Isachenko et al. (2006, 2007, 2008b, 2008c). Bar $=300 \mu \mathrm{m}$.

\section{Hormone assays}

To exclude the possibility that the medium contains relevant amounts of hormones, we determined the level of hormones in native AIM-V medium: $17-\beta$ estradiol $\left(\mathrm{E}_{2}\right)<10 \mathrm{pg} / \mathrm{ml}$ and progesterone $\left(\mathrm{P}_{4}\right)<0.1 \mathrm{ng} / \mathrm{ml}$. $\mathrm{E}_{2}$ concentrations in the supernatants were 365,285 , and $300 \mathrm{pg} / \mathrm{ml}$ respectively, and $\mathrm{P}_{4}$ concentrations were $3.82,1.99$, and $1.95 \mathrm{ng} / \mathrm{ml}$ respectively (Fig. 4).

\section{GAPDH gene expression}

After cryopreservation and cultivation, the samples were used for RNA purification, and the expression of GAPDH in randomly chosen probes (pairwise) was analyzed by conventional RT-PCR (Fig. 5). Figure 5A demonstrates drastically reduced levels of GAPDH gene expression in probes after vitrification ( $3 \%$ agarose gel visualizing the amplified fragments; lines 2-4) in comparison with those after conventional freezing (lines 7-9). For the quantification of this observation, we have chosen some other probes for real-time RT-PCR. Figure 5B presents the typical results of such an analysis: the lines corresponding to the probes after conventional freezing/thawing show more template copies than those corresponding to the probes after vitrification, which reflect great difference in gene expression level. The GAPDH gene expression in ovarian tissue after vitrification was dramatically decreased in contrast to conventional freezing.

\section{Discussion}

Comparative data about vitrification and conventional freezing of human ovarian tissue are limited. Below, we briefly summarize the results of five investigations with different conclusions. 

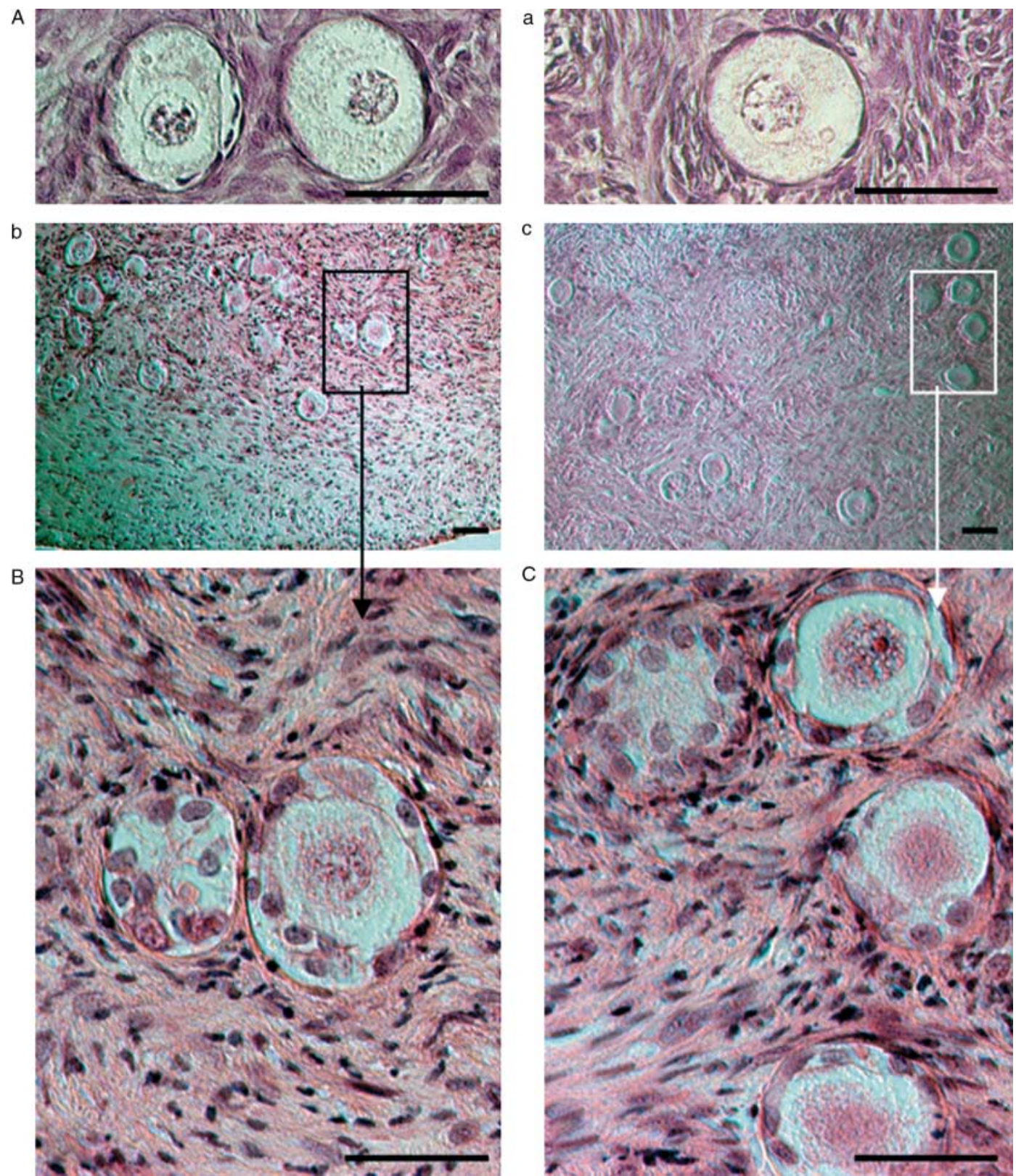

Figure 3 Histological micrographs of follicles from: (A, a) fresh OP; (b) and (B) after vitrification and culture, (c) and (C) after conventional freezing and culture by Isachenko et al. (2006, 2007, 2008a). Bar $=35 \mu \mathrm{m}$.

Comparison of conventional freezing and vitrification of human ovarian tissue was performed by Rahimi et al. (2004). Examination of the necrotic areas of the pieces after both these methods of cryopreservation and transplantation into SCID mice showed no significant difference between these two methods. Such comparative investigations were also performed on human, bovine, and porcine ovarian tissues (Gandolfi et al. 2006). In this study, authors used two vitrification protocols. In the first protocol (Al-Aghbari \& Menino $2002)$, pieces were vitrified in $35 \%$ ethylene glycol $+5 \%$ polyvinylpyrrolidone $+0.4 \mathrm{M}$ trehalose by cooling of tissues in small amount of vitrification medium and post-warming (at $37^{\circ} \mathrm{C}$ ) removal of cryoprotectant in $0.3 \mathrm{M}$ trehalose. According to the second protocol (Silvestre et al. 2002), pieces were vitrified in $22 \%$ ethylene glycol $+22 \%$ DMSO with removal of cryoprotectants in $0.25 \mathrm{M}$ sucrose after warming at $37^{\circ} \mathrm{C}$. Ovarian pieces were also conventionally frozen using $1.5 \mathrm{M}$ DMSO or $1.5 \mathrm{M}$ propylene glycol with post-thawing stepwise exposure of fragments in the respective cryoprotectants (DMSO or propylene glycol) of decreasing concentration (Newton et al. 1996). Immediately after warming/thawing, ovarian 

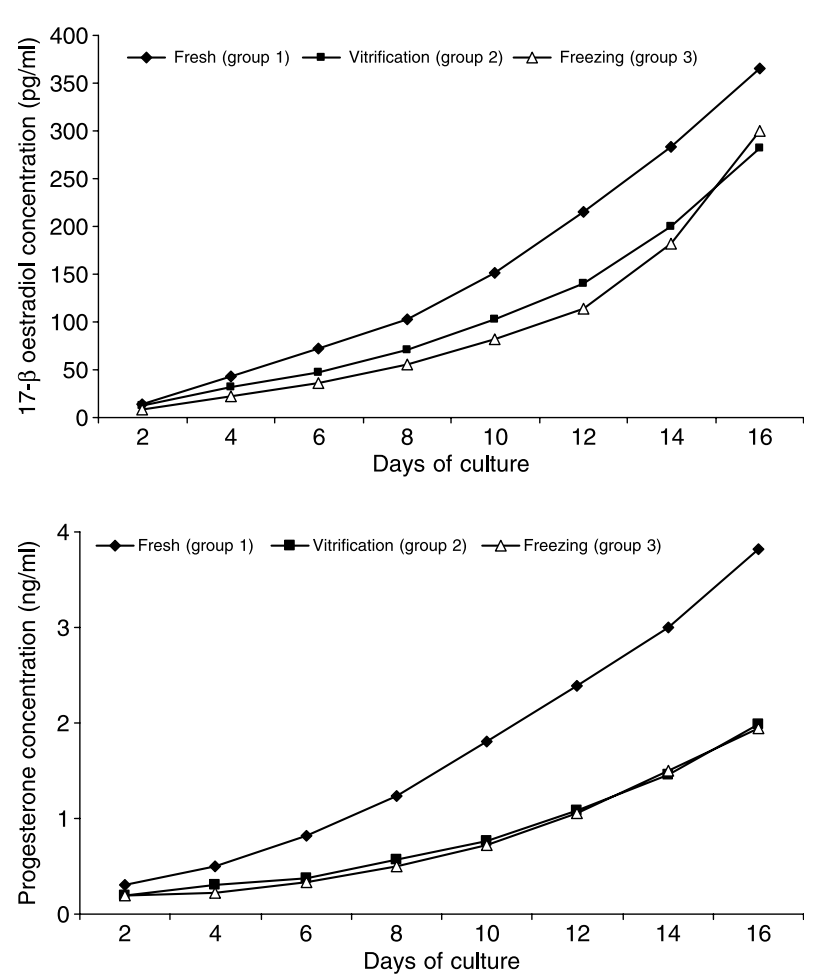

Figure 4 Concentration of $17-\beta$ estradiol and progesterone of vitrified and conventionally frozen ovarian pieces cultured in vitro.

fragments were fixed and follicles were evaluated. The authors of this study have found some peculiarities of cryostability of follicles dependent on species and type of cryoprotectants. However, the central conclusion was the following: conventional freezing is the method of choice for the cryopreservation of ovarian fragments, resulting in a much better preservation of all types of follicles than vitrification (Gandolfi et al. 2006). Our results described in this article suggest the same conclusion about the effectiveness of conventional freezing in comparison with vitrification.

Recently, results from comparative investigations on vitrified and conventionally frozen human ovarian tissue with long term in vitro culture of tissue fragments after thawing/warming have been published (Li et al. 2007). The ovarian strips were divided into two groups. Tissue strips of the first group were vitrified in $2.5 \mathrm{M}(15.6 \%)$ $\mathrm{DMSO}+2.5 \mathrm{M}(15.2 \%)$ propylene glycol+0.2 M sucrose by direct dropping of the vitrification medium into the liquid nitrogen. Warming of the vitrified strips was carried out by direct plunging of the drops of vitrification medium with ovarian tissue and gentle agitation of $0.5 \mathrm{M}$ sucrose at $38{ }^{\circ} \mathrm{C}$ with stepwise rehydration of strips in $0.5,0.25$, and $0.125 \mathrm{M}$ sucrose. Tissue strips of the second group were conventionally frozen in $1.5 \mathrm{M}(11.7 \%) \mathrm{DMSO}+0.1 \mathrm{M}$ sucrose with thawing at $37^{\circ} \mathrm{C}$ and stepwise rehydration in 0.25 and $0.125 \mathrm{M}$ sucrose. After 2 weeks of culture, it was established that in tissues of both cryopreservation groups there was no difference in the proportion of normal follicles after conventional freezing and vitrification (Li et al. 2007). The authors believe that the original methodology of vitrification by direct dropping of freezing solution into liquid nitrogen is as effective as conventional freezing.

In our present investigation, we also have tested the vitrification methodology with direct dropping of ovarian tissue into liquid nitrogen for cooling and into medium for warming as described in Li et al. (2007). Earlier, we have performed comparative investigations of vitrification and conventional freezing for human ovarian tissue. It was established that freezing is a suitable method for cryopreservation because of differences in the quality of follicles: after conventional freezing their quality was higher than after vitrification (Isachenko et al. 2007). Later, a new human ovarian tissue vitrification protocol was applied. The use of this vitrification protocol allows to obtain the high-quality follicles after thawing and culture (Isachenko et al. 2008b). Different
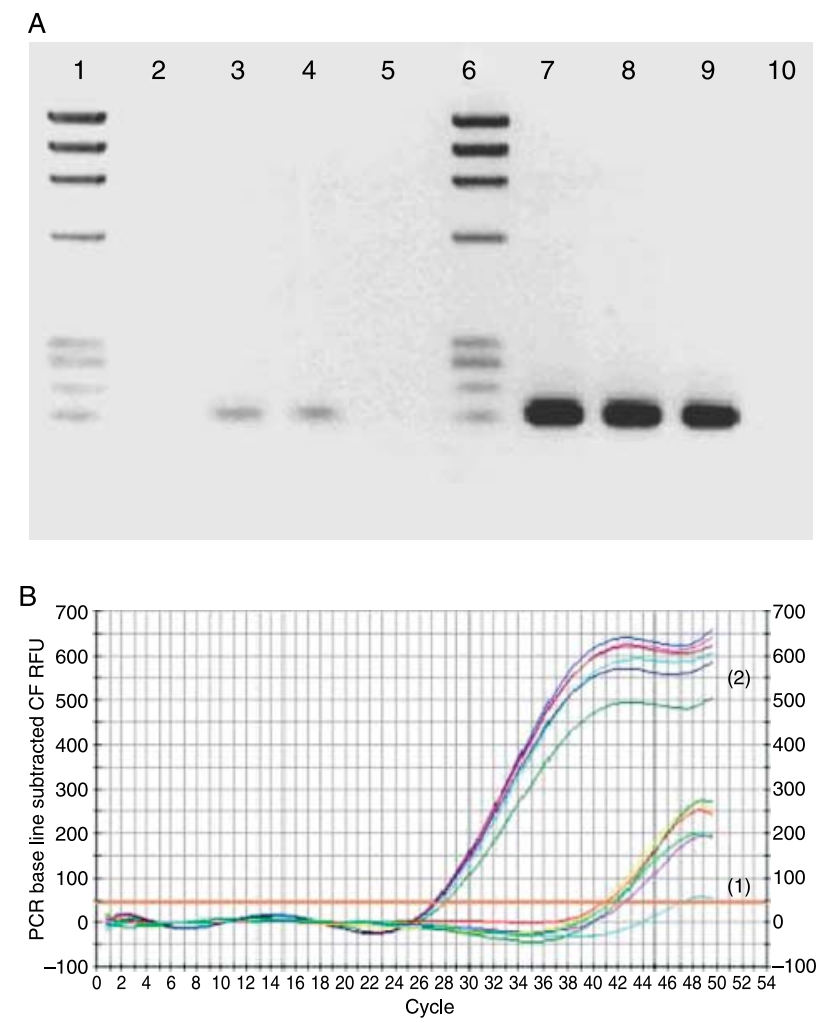

Figure 5 Expression of GAPDH in ovarian tissue after vitrification of samples from three patients (lines 2, 3, and 4) and conventional freezing (lines 7, 8, and 9) (lines 5 and 10 represented a negative control). (A) Analysis of amplified cDNAs by electrophoresis in 3\% agarose gel and ethidium bromide staining. (B) Validation of the results presented on board A by quantitative real-time PCR analysis. Typical amplification curves. Curves for GAPDH gene amplification for the probes after vitrification (1) and conventional freezing (2). CF RFU, curve-fit relative fluorescence units. 
cryoprotectant solutions and types of cooling/warming were tested. The best results were observed in the protocol using 2.62 M DMSO $+2.6 \mathrm{M}$ acetamide+ $1.31 \mathrm{M}$ propylene glycol $+0.0075 \mathrm{M}$ polyethylene glycol. Just this vitrification protocol was tested in the present experiments.

The hormonal activity of thawed and cultured tissue is a criterion for the effectiveness of the particular cryopreservation protocol. It is known that the steroidogenic activity of ovarian tissue is an additional indicator of tissue viability.

Here, we found an enhanced $E_{2}$ production during culture time. The increase in $\mathrm{E}_{2}$ level by incubation time might be due to the fact that relatively more follicles developed into advanced stages during in vitro culture. According to Boland et al. (1993), $E_{2}$ secretion increases with increasing follicular size. The production of $E_{2}$ in in vitro culture of ovarian tissue indicates that the steroidogenic pathways were present in the tissue. However, it is not clear whether steroid production is derived only from follicles, since the follicles were still too small and secretion of $E_{2}$ might be too sparse (Wotiz et al. 1956). The studies in steroid metabolism have shown that hyperplastic stromal cells of ovarian pieces from climacteric patients can produce $E_{2}$ in vivo and in vitro (Wotiz et al. 1956). Steroids could be produced by proliferated stromal tissue, which established a cellular monolayer in response to FCS in the culture medium (Isachenko et al. 2002, 2003). For example, earlier we have vitrified and in vitro cultured human ovarian pieces. Although no follicles were detected in fresh and cultured pieces (Isachenko et al. 2002), the level of $P_{4}$ was as high as in the control group.

The $\mathrm{E}_{2}$ and $\mathrm{P}_{4}$ levels observed in our present studies indicate that the granulosa cells were not luteinized in both control and experimental tissues samples. Here, we have used another type of culture system (Isachenko et al. 2006). This system differs from the former (Isachenko et al. 2002, 2003) in its permanent moving with $75 \mathrm{osc} / \mathrm{min}$ using a rotatory shaker and the big volume of serum-free medium (AIM V) that was not changed during the whole-culture period. A monolayer of stroma of ovarian pieces was not developed. This fact is positive, because by our observation the growing of stroma inhibits the development of follicles (data not shown).

Taking into account that one central aim of ovarian tissue cryopreservation is a post-thawing formation of follicles, the production of steroid hormones is not a highly conclusive test of ovarian tissue viability. Thorough histological examination of the tissue and evidence of undisturbed gene expression are necessary. In fact, a histological test of normality of follicles during in vitro culture is an informative method for evaluation of ovarian tissue viability.
It is established that the RNA in cryopreserved tissues does not undergo significant degradation, the specific contributions of different fixatives and cryopreservation conditions to its degradation are not known and the preliminary estimation of the viability of differentially conserved tissues is often evaluated by the measurement of expression level of widely expressed genes like GAPDH (Fitzpatrick et al. 2002).

Our results obtained in this investigation demonstrate a significant degradation of the large part of intact RNA after vitrification in comparison to conventional freezing. This could be due to inappropriate cryopreservation conditions that allow the mechanical or enzymatic destruction of initially existing RNA. We suppose that our results provide evidence for a difference in the proliferative capacity of frozen and vitrified human ovarian tissues. However, we do not have enough evidence to strongly support this conclusion.

We might speculate that cryopreservation conditions were impaired by microbial contamination. The effective vitrification methodologies are based on the direct cooling of cells in liquid nitrogen. In contrast, conventional freezing completely avoids the direct contact between the liquid nitrogen and the tissue. In fact, any technology in reproductive biology and especially in a medical approach must ensure and guarantee the full protection of biological objects from micro-organisms (Bielanski et al. 2000, 2003). Liquid nitrogen, which is used for the storage of frozen material, can be a source of contamination by these micro-organisms (Tedder et al. 1995, Bielanski et al. 2000). Filtration or u.v. treatment of liquid nitrogen cannot guarantee the absence of contamination of biological material by viruses. For example, contamination of blood probes by hepatitis virus during storage of probes in liquid nitrogen has been reported (Tedder et al. 1995). Different types of virus, which are simple and very cryostable structures, may increase their virulence after a direct plunging and storage in liquid nitrogen, such as hepatitis virus (Hawkins et al. 1996), papova virus (Charles \& Sire 1971), vesicular stomatitis virus (Schaffer et al. 1976), and herpes virus (Jones \& Darville 1989). The main aim of this investigation was to determine whether vitirification is more or less effective than conventional freezing with the ability of the follicles to develop after thawing. In fact, vitrification is technologically promising, it is simpler and one cryo-cycle is less time consuming and cheaper than the conventional freezing method. However, the central goal of cryo-technology is the preservation of intact follicles. Results of the present investigation have also shown that vitrification can guarantee the storage of viable follicles after warming, but conventional freezing is more effective in terms of gene stability.

We report that there is a high rate of follicular survival as well as an increase in $E_{2}$ and $P_{4}$ secretion during in vitro culture after vitrification and conventional 
freezing. These data suggest the viability of the follicle after both procedures and are in contrast with the results of the quantitative PCR. GAPDH is a housekeeping gene and should be present in viable tissue. Even if the GAPDH mRNA expression may be altered by experimental conditions, conclusions based on this alteration can be evaluated as a paradox.

This discrepancy between GAPDH gene expression and hormone secretion is due to two different time points of measurement. This discrepancy can be explained in the following way. For experiments to determine hormonal activity, histological evaluation was performed after post-thawing in vitro culture of ovarian tissue for up to 16 days. In contrast, experiments for $G A P D H$ gene expression were performed after transport of frozen tissue to another laboratory and tissue after thawing was cultured in vitro for up to 5 days only. A decrease in GAPDH gene expression in vitrified ovarian tissue, in contrast to this rate in frozen tissue, can be explained by the necessity of the vitrified tissue to take a longer time to adapt for normal development than frozen tissue. Probably, later, the vitrified tissue will 'catch up' with the frozen tissue and also will demonstrate good GAPDH gene expression. However, the difference in development during the certain time period of in vitro culture allows us to draw the respective conclusion about higher effectiveness of conventional freezing.

It was concluded that for cryopreservation of human ovarian tissue, conventional freezing is more promising than vitrification, because of higher developmental potential.

\section{Materials and Methods}

Except where otherwise stated, all chemicals were obtained from Sigma.

\section{Tissue collection, dissection, and distribution into groups}

Informed consent was obtained from 15 patients aged between 18 and $33(23.1 \pm 4.9)$, under a protocol approved by the University Ethics Board. Ovarian tissue fragments were transported to the laboratory within $22-25 \mathrm{~h}$ in a special, isolated transport box (DeltaT $\mathrm{GmbH}$, Giessen, Germany) that can maintain a stable temperature between 4 and $8{ }^{\circ} \mathrm{C}$ for $36 \mathrm{~h}$, containing a transport medium (Brama I; CryoBioSystem, L'Aigle, France) specially developed for ovarian tissue.

Tweezers and scalpel No 22 were used for dissection of medulla and for further division of ovarian tissue fragments into small pieces. The dissection of ovarian tissue was done in a medium specially developed for this purpose (Brama II, CryoBioSystem). A small sample of ovarian tissue of each patient was removed for routine histology and follicle counts and immediately fixed with Bouin's solution. Small pieces measuring $\sim 1 \mathrm{~mm}^{3}$ of experimental ovarian tissue were randomly distributed as follows: non-treated fresh control group 1 (immediately after transport to the laboratory; $n=45$ ); 'vitrification' group $2(n=45)$; and freezing group $3(n=45)$.

\section{Vitrification}

Previously, we have chosen from 18 protocols the optimal one (Isachenko et al. 2008b). Just this protocol was used for the present research.

The vitrification solution, prepared on Dulbecco's phosphate-buffered solution with serum substitute supplement (SSS, Irvine Sci., St Ana, CA, USA) and antibiotic-antimycotic, contained $2.62 \mathrm{M}$ DMSO, 2.60 M acetamide, $1.31 \mathrm{M}$ propylene glycol, and $0.0075 \mathrm{M}$ polyethylene glycol. The ovarian tissue pieces (OPs) were dehydrated in vitrification solution of increased concentration: $12.5,25,50$, and $100 \%$. The first two steps were performed at room temperature, which lasted $5 \mathrm{~min}$ each, and the next two steps lasted $15 \mathrm{~min}$ each at $4{ }^{\circ} \mathrm{C}$. After this last step of saturation by cryoprotectants, the OPs were dropped directly into liquid nitrogen, together with a small volume $(\sim 20 \mu \mathrm{l})$ of $100 \%$ vitrification solution.

For warming, the vitrified OPs were directly plunged into $10 \mathrm{ml}$ of $40^{\circ} \mathrm{C}$ pre-warmed $50 \%$ vitrification solution under gentle shaking with vortex until the ice melted. The dilution of the cryoprotectants was performed in a decreasing concentration of vitrification solution (25 and 12.5\%) at room temperature and OPs were finally washed thrice in a culture medium at $37^{\circ} \mathrm{C}$ and $5 \% \mathrm{CO}_{2}$. Each step of the dilution protocol lasted $5 \mathrm{~min}$.

\section{Conventional freezing}

The freezing protocol was based on the protocols that were used by Gosden et al. (1994), Gosden (2000, 2002) with some modifications. Standard 1.8 cryo-vials (Nunc, Roskilde, Denmark) were filled with $1.8 \mathrm{ml}$ freezing medium containing L-15 Medium (Leibovitz) with L-glutamine +1.5 M DMSO $+0.1 \mathrm{M}$ sucrose $+10 \%$ SSS (Irvine Sci.), and were cooled in ice water $\left(0^{\circ} \mathrm{C}\right)$. Then, OPs were transferred to cryo-vials and these cryo-vials were introduced in ice water for $30 \mathrm{~min}$. After that, cryo-vials were placed in the freezer, the freezing chamber of which was previously stabilized to $2{ }^{\circ} \mathrm{C}$ for 20-30 min. The freezing program was as follows: 1) the starting temperature was at $2{ }^{\circ} \mathrm{C} ; 2$ ) cooling from $2{ }^{\circ} \mathrm{C}$ to $-6{ }^{\circ} \mathrm{C}$ at a rate of $-2{ }^{\circ} \mathrm{C} / \mathrm{min}$; 3 ) auto-seeding initiated at $-6{ }^{\circ} \mathrm{C}$; 4) after beginning of crystal formation, the temperature increased to $-5.7{ }^{\circ} \mathrm{C}$ and remained at this temperature for $10 \mathrm{~min}$; 5) cooling from $-5.7{ }^{\circ} \mathrm{C}$ to $-40^{\circ} \mathrm{C}$ at a rate of $-0.3^{\circ} \mathrm{C} / \mathrm{min}$; 6) cooling to $-140^{\circ} \mathrm{C}$ at a rate of $-10^{\circ} \mathrm{C} / \mathrm{min}$ and plunging of cryo-vials into liquid nitrogen.

The procedure of thawing was achieved by holding the vials for $30 \mathrm{~s}$ at room temperature followed by immersion in a $100{ }^{\circ} \mathrm{C}$ (boiling) water bath for $60 \mathrm{~s}$, and expelling the contents of the tubes into the solution for the removal of cryoprotectants. The exposure time in the boiling water was visually controlled by the presence of ice in the medium; as soon as the ice was 
$\sim 2 \mathrm{~mm}$ apex, the tube was expelled from the boiling water. The final temperature of medium after expelling from $10^{\circ} \mathrm{C}$ water bath ranged between 4 and $10{ }^{\circ} \mathrm{C}$. After thawing, OPs were transferred within a few seconds (5-7) to a $100 \mathrm{ml}$ specimens container (Sarstedt, Nuemrecht, Germany) with $10 \mathrm{ml}$ solution for removal of cryoprotectants $(0.75 \mathrm{M}$ sucrose $+10 \%$ SSS + L-15 medium). The stepwise dilution of cryoprotectants was achieved using the same principle as that used for saturation by ethylene glycol (see Fig. 1 in Isachenko et al. 2006). The container was placed on the shaker and continuously agitated with $200 \mathrm{osc} / \mathrm{min}$ for $15 \mathrm{~min}$ at room temperature. Stepwise rehydration of OPs for $30 \mathrm{~min}$ at room temperature was also performed using the same dropping methodology (Isachenko et al. 2006). For dropping rehydration, we used $50 \mathrm{ml}$ of holding solution ( $\mathrm{L}-15$ medium $+10 \% \mathrm{SSS}$ ) in a $50 \mathrm{ml}$ tube (Greiner Bio-One $\mathrm{GmbH}$, Frickenhausen, Germany). This method includes the slow adding (dropping) of holding medium to the solution of sucrose with OPs. The final sucrose concentration was $0.125 \mathrm{M}$. Finally, the OPs were washed thrice each in DPBS supplemented with $10 \%$ SSS and in culture medium for $10 \mathrm{~min}$. After warming and washing, OP was transferred for in vitro culture.

\section{Culture}

Pieces of control (group 1) immediately after receipt of transport box and experimental pieces after cryopreservation (groups 2 and 3) were translocated to $200 \mathrm{ml}$ dishes for suspension culture (Cellstar, Greiner Bio-One $\mathrm{GmbH}$ ) with $30 \mathrm{ml} \mathrm{AIM-V}$ medium (Gibco) for in vitro culture at $37^{\circ} \mathrm{C}$ in $5 \%$ $\mathrm{CO}_{2}$ with $75 \mathrm{osc} / \mathrm{min}$ agitation using a rotation shaker. From each patient, two pieces were used for determination of hormonal activity during $16 \mathrm{~d}$ culture and histological evaluation at the end of this culture and one piece was used for study of GAPDH gene expression for up to $5 \mathrm{~d}$ culture.

\section{Histological examination}

For histological investigation, tissue pieces from up to $16 \mathrm{~d}$ in vitro culture were fixed in Bouin's solution, embedded in paraffin wax, serially sectioned at $5 \mu \mathrm{m}$, stained with hematoxylin/eosin, and analyzed under a microscope $(\times 400)$. The number of viable and damaged follicles was counted. To avoid over counting of the same follicles, only the section with a visible oocyte nucleus was counted.

Morphology of follicles was evaluated by considering the parameters previously described by Paynter et al. (1999). Two types of follicles were evaluated: 1) primordial follicles composed of an oocyte surrounded by a layer of flattened follicular cells and 2) primary follicles that are similar to primordial follicles, but surrounded by one to two layers of spheroid granulosa cells. The qualities of follicles were graded from one to three. A follicle of grade 1 is spherical and is randomly distributed around oocytes' granulosa cells, with homogenous cytoplasm and slightly granulated nucleus, in the center of which condensed chromatin in the form of dense spherical structure is detected. A follicle of grade 2 has the same peculiarities, but the granulosa cells cover irregular oocytes; these cells can be flat and condensed chromatin is not detected in cytoplasm. A follicle of grade 3 has partly or fully disrupted granulosa or cytoplasm and picnotic nucleus. Follicles of grades 1 and 2 were denoted as normal and those of grade 3 were denoted as degenerated. Examples of the different follicular degenerations can be observed elsewhere (for example, see Isachenko et al. (2008b, 2008c)).

\section{Hormone assays}

The medium after culturing of cryopreserved and fresh OP was collected every second day $(300 \mu \mathrm{l}$ per collection) during culture and stored at $-80{ }^{\circ} \mathrm{C}$ for $1-2$ months for subsequent hormone assays. The level of $\mathrm{E}_{2}$, analytical sensitivity $5.0 \mathrm{pg} / \mathrm{ml}$ ) and $\mathrm{P}_{4}$, analytical sensitivity $0.1 \mathrm{ng} / \mathrm{ml}$ ) was measured using heterogeneous competitive magnetic separation immunoassay (Bayer Vital $\mathrm{GmbH}$ ).

\section{GAPDH-gene expression}

After in vitro culture of ovarian pieces, total RNA preparation, RT, PCR, and real-time PCR were performed by the following methodology. Fifteen ovarian pieces (one piece from patient) were mechanically disrupted and homogenized, total RNA was extracted using GenElute Total RNA purification kit, and residual genomic DNA was removed by DNase I treatment (Sigma) according to the manufacturer protocols. One microgram of each total RNA was reverse transcribed using random hexamers and Superscript II reverse transcriptase (Invitrogen). PCRs contained $1 \times$ PCR RedTaq Ready Master Mix, $500 \mathrm{nM}$ of each GAPDH primer (forward: $5^{\prime}$-ggtatcgtggaaggactcatgac- $3^{\prime}$; reverse: $5^{\prime}$-atgccagtgagcttcccgttcagc- $3^{\prime}$ ), and template in a total volume of $10 \mu \mathrm{l}$. The thermal profile used for amplification was $95^{\circ} \mathrm{C}$ for $5 \mathrm{~min}$ followed by 35 cycles of $95{ }^{\circ} \mathrm{C}$ for $15 \mathrm{~s}, 58{ }^{\circ} \mathrm{C}$ for $20 \mathrm{~s}$, and $72{ }^{\circ} \mathrm{C}$ for $40 \mathrm{~s}$. PCR products were visualized by acryl amide (7.5\%) or agarose (3\%) gel electrophoresis.

The results were validated by real-time PCR approach used the SYBR green assay in a 96-well plate format using a Bio-Rad iCycler. Reactions contained $1 \times$ SYBR MasterMix (Qiagen), $300 \mathrm{nM}$ of each primer, $10 \mathrm{nM}$ of Calibration Dye, and template in a total volume of $15 \mu \mathrm{l}$. The thermal profile used for amplification was $95^{\circ} \mathrm{C}$ for $8 \mathrm{~min}$ followed by 50 cycles of $95{ }^{\circ} \mathrm{C}$ for $15 \mathrm{~s}, 58{ }^{\circ} \mathrm{C}$ for $20 \mathrm{~s}$, and $72{ }^{\circ} \mathrm{C}$ for $30 \mathrm{~s}$. At the end of the amplification phase, a melting-curve analysis was carried out on the products formed.

\section{Statistical analysis}

The effects of cryopreservation on the production of hormones and development of follicles were evaluated by ANOVA. The level of statistical significance was set at $P<0.05$.

\section{Declaration of interest}

The authors declare that there is no conflict of interest that could be perceived as prejudicing the impartiality of the research reported. 


\section{Funding}

Research was supported by ESF, Project Nr. 2007000003.

\section{References}

Al-Aghbari AM \& Menino AR 2002 Survival of oocytes recovered from vitrified sheep ovarian tissue. Animal Reproduction Science 71 101-110.

Andersen CY, Rosendahl M, Byskov AG, Loft A, Ottosen C, Dueholm M, Schmidt KL, Andersen AN \& Ernst E 2008 Two successful pregnancies following autotransplantation of frozen/thawed ovarian tissue. Human Reproduction 23 2266-2272.

Barber RD, Harmer DW, Coleman RA \& Clark BJ 2005 GAPDH as a housekeeping gene: analysis of GAPDH mRNA expression in a panel of 72 human tissues. Physiological Genomics 2 389-395.

Bedaiwy M \& Falcone T 2007 Harvesting and autotransplantation of vascularized ovarian grafts: approaches and techniques. Reproductive Biomedicine Online 14 360-371.

Bielanski A, Nadin-Davis S, Sapp T \& Lutze-Wallace C 2000 Viral contamination of embryos cryopreserved in liquid nitrogen. Cryobiology $40110-116$.

Bielanski A, Bergeron H, Lau PCK \& Devenish J 2003 Microbial contamination of embryos and semen during long term banking in liquid nitrogen. Cryobiology 46 146-152.

Boland NI, Humpherson PG, Leese HJ \& Gosden RG 1993 Pattern of lactate production and steroidogenesis during growth and maturation of mouse ovarian follicles in vitro. Biology of Reproduction 48 798-806.

Callejo J, Salvador C, Miralles A, Vilaseca S, Lailla JM \& Balasch J 2001 Long-term ovarian function evaluation after autografting by implantation with fresh and frozen-thawed human ovarian tissue. Journal of Clinical Endocrinology and Metabolism 86 4489-4494.

Charles GN \& Sire DJ 1971 Transmission of papova virus by cryotherapi applicator. Journal of the American Medical Association 2181435.

Demeestere I, Simon P, Buxant F, Robin V, Fernandez SA, Centner J, Delbaere A \& Englert Y 2006 Ovarian function and spontaneous pregnancy after combined hetorotopic and orthotopic cryopreserved ovarian tissue transplantation in a patient previously treated with bone marrow transplantation: case report. Human Reproduction 21 2010-2014.

Demeestere I, Simon P, Emiliani S, Delbaere A \& Englert Y 2007 Fertility preservation: successful transplantation of cryopreserved ovarian tissue in a young patient previously treated for Hodgkin's disease. Oncologist 12 1437-1442.

Donnez J \& Bassil S 1998 Indications for cryopreservation of ovarian tissue. Human Reproduction Update 4 248-259.

Donnez J, Dolmans MM, Demylle D, Jadoul P, Pirard C, Squifflet J, MartinezMadrid B \& van Langendonckt A 2004 Livebirth after orthotopic transplantation of cryopreserved ovarian tissue. Lancet 364 1405-1410.

Donnez J, Martinez-Madrid B, Jadoul P, Van Langendonckt A, Demylle D \& Dolmans MM 2006a Ovarian tissue cryopreservation and transplantation: a review. Human Reproduction Update 12 519-535.

Donnez J, Dolmans MM, Demylle D, Jadoul P, Pirard C, Squifflet J, Martinez-Madrid B \& Van Langendonckt A 2006b Restoration of ovarian function after orthotopic (intraovarian and periovarian) transplantation of cryopreserved ovarian tissue in a woman treated by bone marrow transplantation for sickle cell anaemia: case report. Human Reproduction 21 183-188.

Donnez J, Squifflet J, Van Eyck AS, Demylle D, Jadoul P, Van Langendonckt A \& Dolmans MM 2008 Restoration of ovarian function in orthotopically transplanted cryopreserved ovarian tissue: a pilot experience. Reproductive Biomedicine Online 16 694-704.

Fitzpatrick R, Casey OM, Morris D, Smith T, Powell R \& Sreenan JM 2002 Postmortem stability of RNA isolated from bovine reproductive tissues. Biochimica et Biophysica Acta 1574 10-14.

Gandolfi F, Paffoni A, Brambilla EP, Bonetti S, Brevini TAL \& Ragni G 2006 Efficiency of equilibrium cooling and rapid freezing procedures for the cryopreservation of ovarian tissue: comparative analysis between human and animal models. Fertility and Sterility 85 1150-1156.

Gosden RG 2000 Low temperature storage and grafting of human ovarian tissue. Molecular and Cellular Endocrinology 163 125-129.

Gosden RG 2002 Gonadal tissue cryopreservation and transplantation. Reproductive Biomedicine Online 4 64-67.
Gosden RG 2005 Prospects for oocyte banking and in vitro maturation. Journal of the National Cancer Institute 34 60-63.

Gosden RG, Baird DT, Wade JC \& Webb R 1994 Restoration of fertility to oophorectomized sheep by ovarian autografts stored at $-196^{\circ} \mathrm{C}$. Human Reproduction 9 597-603.

Grovas A, Fremgen A, Rauck A, Ruymann FB, Hutchinson CL, Winchester DP \& Menck HR 1997 The National Cancer Data Base report on patterns of childhood cancers in the United States. Cancer $802321-2332$.

Hawkins AE, Zuckerman MA, Briggs M, Gilson RJ, Goldstone AH, Brink NS \& Tedder RS 1996 Hepatitis B nucleotide sequence analysis: linking an outbreak of acute hepatitis B to contamination of a cryopreservation tank. Journal of Virological Methods 60 81-88.

Hovatta O 2005 Methods for cryopreservation of human ovarian tissue. Reproductive Biomedicine Online 10 729-734.

Hovatta O, Silye R, Krausz T, Abir R, Margara R, Trew G, Lass A \& Winston RM 1996 Cryopreservation of human ovarian tissue using dimethylsulphoxide and propanediol-sucrose as cryoprotectants. Human Reproduction 11 1268-1272.

Isachenko V, Isachenko E, Rahimi G, Krivokharchenko A, Alabart JL \& Nawroth F 2002 Cryopreservation of human ovarian tissue by direct plunging into liquid nitrogen: negative effect of disaccharides in rapid freezing solution. Cryo Letters 23 333-344.

Isachenko V, Isachenko E, Rahimi G \& Nawroth F 2003 Cryopreservation of human ovarian tissue by direct plunging into liquid nitrogen. European Journal of Obstetrics, Gynecology, and Reproductive Biology 108 186-193.

Isachenko V, Montag $\mathrm{M}$, Isachenko $\mathrm{E}$, van der Ven $\mathrm{K}$, Dorn $\mathrm{C}$, Roesing $\mathrm{B}$, Braun F, Sadek F \& van der Ven H 2006 Effective method for in vitro culture of cryopreserved human ovarian tissue. Reproductive Biomedicine Online 13 228-234.

Isachenko V, Isachenko E, Reinsberg J, Montag M, van der Ven K, Dorn C, Roesing B \& van der Ven H 2007 Cryopreservation of human ovarian tissue: comparison of rapid and conventional freezing. Cryobiology $\mathbf{5 5}$ 261-268.

Isachenko V, Isachenko E, Kreienberg R \& Weiss JM 2008a Eine Kryobank für humanes ovarialgewebe: konzept und perspektiven. Frauenarzt 49 518-521.

Isachenko E, Isachenko V, Nawroth F, Rahimi G, Kreienberg R, Reisnberg R \& Weiss J 2008b Human ovarian tissue preservation: is vitrification acceptable method for assisted reproduction? Cryo Letters 29 301-314.

Isachenko V, Isachenko E, Reinsberg J, Montag M, Weiss J, Braun F \& van der Ven H 2008c Simplified technique of human ovarian tissue freezing: quick cooling from $-36^{\circ} \mathrm{C}$. Cryo Letters 29 261-268.

Jemal A, Siegel R, Ward E, Hao Y, Xu J, Murray T \& Thun M 2008 Cancer statistics, 2008. CA: A Cancer Journal for Clinicians 58 71-96.

Jones SK \& Darville JM 1989 Transmission of virus-partcles by cryo-therapi and multi-use caustic pencils: a problem to dermatologist? British Journal of Dermatology 121 481-486.

Li YB, Zhou CG, Yang GF, Wang O \& Dong Y 2007 Modified rapid freezing method for cryopreservation of human ovarian tissue. Chinese Medical Journal 120 110-114.

Meirow D \& Nugent D 2001 The effects of radiotherapy and chemotherapy on female reproduction. Human Reproduction Update 7 534-543.

Meirow D, Levron J, Eldar-Geva T, Hardan I, Fridman E, Zalel Y, Schiff E \& Dor J 2005 Pregnancy after transplantation of cryopreserved ovarian tissue in a patient with ovarian failure after chemotherapy. New England Journal of Medicine 353 318-321.

Meirow D, Levron J, Eldar-Geva T, Hardan I, Fridman E, Yemini Z \& Dor J 2007 a Monitoring the ovaries after autotransplantation of cryopreserved ovarian tissue: endocrine studies, in vitro fertilization cycles, and live birth. Fertility and Sterility 87 418.e7-418.e15.

Meirow D, Baum M, Yaron R, Levron J, Hardan I, Schiff E, Nagler A, Yehuda DB, Raanani H, Hourvitz A et al. 2007b Ovarian tissue cryopreservation in hematologic malignancy: ten years' experience. Leukemia \& Lymphoma 48 1569-1576.

Newton H, Aubard Y, Rutherford A, Sharma V \& Gosden R 1996 Low temperature storage and grafting of human ovarian tissue. Human Reproduction 11 1487-1491.

Oktay K \& Karlikaya G 2000 Ovarian function after transplantation of frozen, banked autologous ovarian tissue. New England Journal of Medicine 3421919. 
Oktay K, Newton H, Aubard Y, Salha O \& Gosden RG 1998 Cryopreservation of immature human oocytes and ovarian tissue: an emerging technology? Fertility and Sterility 69 1-7.

Oktay K, Buyuk E, Veeck L, Zaninovic N, Xu K, Takeuchi T, Opsahl M \& Rosenwaks Z 2004 Embryo development after heterotopic transplantation of cryopreserved ovarian tissue. Lancet 3639412.

Paynter SJ, Cooper A, Fuller BJ \& Shaw RW 1999 Cryopreservation of bovine ovarian tissue: structural normality of follicles after thawing and culture in vitro. Cryobiology 38 301-309.

Radford JA, Lieberman BA, Brison DR, Smith AR, Critchlow JD, Russell SA, Watson AJ, Clayton JA, Harris M, Gosden RG et al. 2001 Orthotopic reimplantation of cryopreserved ovarian cortical strips after high-dose chemotherapy for Hodgkin's lymphoma. Lancet 357 1172-1175.

Rahimi G, Isachenko E, Isachenko V, Sauer H, Wartenberg M, Tawadros S, Hescheler J, Mallmann P \& Nawroth F 2004 Comparison of necrosis in human ovarian tissue after conventional slow conventional freezing or rapid freezing and transplantation in ovariectomized SCID mice. Reproductive Biomedicine Online 9 187-193.

Rosendahl M, Loft A, Byskov AG, Ziebe S, Schmidt KT, Andersen AN, Ottosen C \& Andersen CY 2006 Biochemical pregnancy after fertilization of an oocyte aspirated from a heterotopic autotransplant of cryopreserved ovarian tissue: case report. Human Reproduction $\mathbf{2 1}$ 2006-2009.

Schaffer TW, Everett J, Silver GH \& Came E 1976 Biohazard: viruscontaminated liquid nitrogen. Science 192 25-26.

Schmidt KL, Andersen CY, Loft A, Byskov AG, Ernst E \& Andersen AN 2005 Follow-up of ovarian function post-chemotherapy following ovarian cryopreservation and transplantation. Human Reproduction 20 3539-3546.

Silber SJ \& Gosden R 2007 Ovarian transplantation in a series of monozygotic twins discordant for ovarian failure. New England Journal of Medicine 356 1382-1384.
Silber SJ, Lenahan KM, Levine DJ, Pineda JA, Gorman KS, Friez MJ, Crawford EC \& Gosden RG 2005 Ovarian transplantation between monozygotic twins discordant for premature ovarian failure. New England Journal of Medicine 353 58-63.

Silvestre MA, Saeed AM, Escriba MJ \& Garcia-Ximenes F 2002 Rapid freezing and rapid conventional freezing of rabbit fetal tissues and skeen samples from rabbits and pigs. Theriogenology 58 69-76.

Sirover MA 1996 Emerging new functions of the glycolytic protein, glyceraldehyde-3-phosphate dehydrogenase, in mammalian cells. Life Sciences 58 2271-2277.

Sirover MA 1997 Role of the glycolytic protein, glyceraldehyde-3phosphate dehydrogenase, in normal cell function and in cell pathology. Journal of Cellular Biochemistry 66 133-140.

Tedder RS, Zuckerman MA, Goldstone AH, Hawkins AE, Fielding A, Briggs EM, Irwin D, Blair S, Gorman AM, Patterson KG et al. 1995 Hepatitis B transmission from contaminated cryopreservation tank. Lancet 346 137-140.

Wolner-Hanssen P, Haegglund L, Ploman F, Ramirez A, Manthorpe R \& Thuring A 2005 Autotransplantation of cryopreserved ovarian tissue to the right forearm $4(1 / 2)$ years after autologous stem cell transplantation. Acta Obstetricia et Gynecologica Scandinavica $\mathbf{8 4}$ 695-698.

Wotiz HH, Davis JW, Lemon HM \& Gut M 1956 Studies in steroid metabolism. V. The conversion of testosterone-4- $\mathrm{C}^{14}$ to estrogens by human ovarian tissue. Journal of Biological Chemistry 222 487-501.

Received 6 February 2009

First decision 10 March 2009

Revised manuscript received 17 April 2009

Accepted 13 May 2009 